\title{
MYCENAEAN SEALS AND SEALINGS
}

\section{JOHN G. YOUNGER}

After the introduction of a sealing system from the Near East into southern Greece in the Early Helladic period (see Wiencke, this volume) and the destruction of that culture ca. 2200 BCE, there is no demonstrable sign of seal use on the Greek mainland until the sudden appearance of seals in the Mycenae Shaft Graves at the end of the Middle Helladic period.

After the Shaft Grave period, seals are known on the Greek mainland, but there is almost no evidence that seals are being carved there, with the possible exception of the Mycenae-Vapheio group (mentioned later). A stone mold for a gold ring found in a tomb at Eleusis (CMS V, 422) constitutes the slim evidence for the making of seals on the Greek mainland (cf. Evely 1993, 146-71).

Perhaps almost all seals used on the Greek mainland in the Late Bronze were made in Crete. Certainly the seals in most stylistic groups cluster predominately in Crete, and after the fall of Knossos brought an end to hard stone seal engraving (ca. 1300 BCE; Weingarten this volume), the administrators at Mycenae and Pylos used heirloom seals to impress sealings (Younger 1981a). Furthermore, after the fall of Knossos, Mycenaeans produced the Mainland Popular group, a series of beads in soft stones and glass that look like seals but were//ever used administratively (Younger 1987a; Pini 1995; Dickers 2001). One might say, then, that the Mycenaeans used seals in imitation of Minoan seal use but that tradition sat thinly on Mycenaean culture. 


\section{Before the Late Bronze Age}

In the Late Neolithic period, clay and stone stamps are found from central Europe and Italy to the eastern Mediterranean (Makkay 1984, 2005; Younger 1987b). Because their intaglio designs are simple and a few preserve traces of color (yellow and red), it is believed that they were used to imprint designs on cloth-whence the term pintaderas.

The Early Helladic stamp seals (Wiencke this volume) may have arisen from pintaderas - their shapes are similar and their designs look like textile patterns. These stamps were used in a sealing administration, apparently derived from the Near East (see Weingarten, this volume).

One seal impression from Kea points in the direction that the EH/EC II culture would have taken if left to flourish. A stamped hearth rim (CMS V, 478) parodies Egyptian hieroglyphs, including a djed pillar, $R a$ sun sign, and a vase sign. The last is especially clever, for in Egyptian it would be the typical amphora, but here, in the EC II Aegean, it is the typical sauceboat. Obviously someone in the central Aegean knew enough about Egyptian writing to poke intelligent fun at it.

After the EH II destructions, the mainlanders abandoned seals. Yet a few clay stamps are found in Middle Helladic contexts (Younger 1992); perhaps these represent a resuscitation of pintaderas, as if lurking beneath the sophisticated surface of $\mathrm{EH}$ II administrative sealing there had been a local tradition of stamping waiting to reemerge.

\section{The Shaft Grave Period}

Until the end of the Middle Helladic period, only the islands (e.g., Kea and Samothrace) are acquainted with Minoan seals. But in MH III-LH I, the shaft graves at Mycenae begin attracting seals in number. In Grave Circle B come two Talismanics (CMS I, 6, 7) and a tiny amethyst disk (CMS I, 5) engraved with a portrait head of a bearded man; both are Minoan imports.

From Circle A come three gold cushions (CMS I, 9-11) and three stone seals (CMS I, 12-14), all from Shaft Grave III and two gold rings (CMS I, 15, 16) from Shaft Grave IV; a third gold ring (CMS I, 17) comes from the nearby "Mycenae Treasure." These trios from Grave Circle A (and vicinity) provoke a thought: Might they refer to another triadic series? Grave Circle B encloses approximately twelve major tombs, and Grave Circle A contains six shaft graves. After the Shaft Grave period, the Mycenae elite are buried in tholoi, which cluster in three geographical areas (near the citadel, and on both sides of the Panagia Ridge) and in three distinct periods (LH I-II, II late, and IIIA-B early). Is it possible that Mycenae had three major kinship groups that shared power (French 1989)? The 
Lion Gate relief may present the venue for their power: Two lions (military) stand on two altars with concave sides (religion) and flank a column (palatial administration).

\section{The Major Mycenaean, or Mycenaean-Inspired, Stylistic Groups}

\section{The Mycenae-Vapheio Lion Group}

The three gold cushions from Shaft Grave III present a distinct kind of lion: powerful body, fishgill-like separation between head and mane, heavy forelegs rounded at the top and outlined by a separate line topped by a dot, a sinuous saphenous vein over the legs, fur on belly and haunch, and heavily dotted paws (figure 25.1; MH III-LH I [-LH II]; Younger 1978, 1984, 1987a). The same lion appears on many seals from the Vapheio cist (LH IIA; e.g., CMS I, 243, 250). Another seal from the Vapheio cist (CMS I, 223) presents an equally powerful griffin, also with saphenous veins, led on a leash by a robed man wearing a seal stone on his left wrist (Rehak 1994). Other objects also present the same lion (e.g., the lion-hunt niello dagger and the gold lioness-head rhyton, both from Shaft Grave IV; Marinatos and Hirmer 1960, color pls. XXXV, XXXVII, XXXIX).

These seals and other objects constitute a major style called the MycenaeVapheio style because many of the pieces come from these two sites. To this core

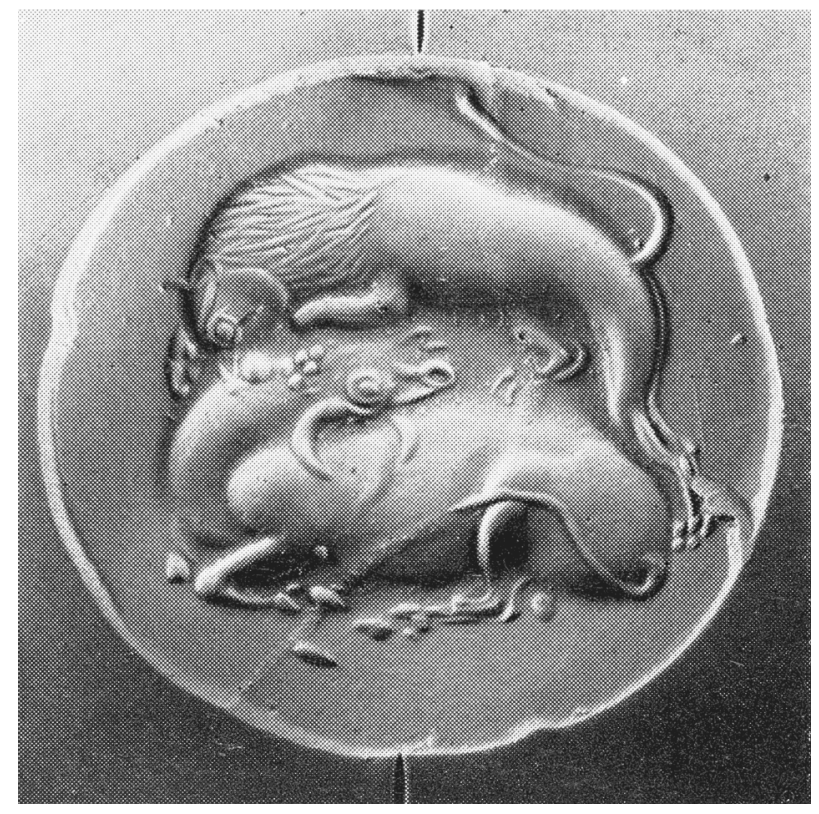

Figure 25.1. Modern impression of a lentoid (CMS V 435) in the Mycenae-Vapheio Lion group, from the Nichoria tholos (photo courtesy CMS). 
group other seals are related (Younger 1981b), for instance the badly cut lion on CMS I, 228, from the Vapheio chamber, which has the fishgill but nothing else. The Lion Gate relief has powerful lions with the saphenous vein and outlined forelegs, but it adds "bracelets" across the ankles paralleled on a seal (CMS I, 46) from Mycenae Chamber Tomb 8 (LH II context?) that carries almost the same scene: two lions on an altar with concave sides sharing a frontal face.

Only a few examples of the Mycenae-Vapheio group come from Crete. From Knossos comes one sealing (CMS II.8, 297), while a few others may be peripherally related (from Kato Zakro, CMS II.7, 75, cf. 74, and from Ayia Triada, CMS II.6, 104).

If the Mycenae-Vapheio group was created on the Mainland, it is the only seal stone workshop that can, with any plausibility, be located there.

\section{The Spectacle Eye Group (LH IIIA)}

When the Mycenaeans took over Knossos, they commissioned a new style for seals, the Spectacle Eye group (Weingarten this volume; Younger 2000; Müller 2000); its animals look like they are wearing eyeglasses. Since the group also employs lapis lacedaemonius (a stone found only south of Sparta on the Greek mainland) and creates a new iconography (animals in bilateral symmetry and the Minotaur), it is likely that this group is an invention to mark the new Mycenaean administration at Knossos.

\section{The Island Sanctuaries Group (End of LH IIIA)}

Known for its animals with svelte bodies, linear legs with dotted hooves and joints, and contorted poses, the Island Sanctuaries seals, and its subset, Rhodian Hunt, are the last seals to be made in hard stone; no more developed stylistic group of seals exists (Younger 1979, 1981a). Since only one, possibly three, Rhodian Hunt seals impressed Knossos sealings (CMS II.8, 192, possibly 186, 187) and since most seals in this group have been found in the Cyclades and Dodecanese, including many in Mycenaean sanctuaries, it is tempting to hypothesize that the group had just begun to develop at Knossos when the palace fell and the artists dispersed.

\section{Mainland Popular Seals and Related Groups (End of LH IIIA-IIIB)}

With the demise of hard stone seal engraving (perhaps always more a Minoan art), there arose a group of soft stone seals with schematic, linear depictions of animals, occasionally people, known as the Mainland Popular group (Younger 1987a; Pini 1995; Dickers 2001). The name derives from the fact that the seals are restricted to the Greek mainland (a subset, the Armenoi group, in Mycenaean Crete) and to humble tombs scattered broadly across the Aegean; two Mainland Popular seals even come from the Uluburun wreck (dated after 1306 BC by dendrochronology; CMS VS.1B, 473; VS.3, 454). This widespread dispersal of Mainland Popular seals, 
their appearance at nonpalatial sites, and the fact that they impressed virtually no sealings (one exception from Thebes: CMS VS 3.373), all make it likely that these seals served as the identity markers of commoners, much as did the Messara dentine seals of EM II-III, soft stone prisms from the Malia Workshop in MM II (Poursat 1996), and the Cretan Popular group in LM I (Younger 1983)

With the Mainland Popular group, the manufacture of seals in the Bronze Age Aegean comes to an end.

\section{The Prepalatial Use of Seals on the Greek Mainland}

There is no direct evidence for seal use in the Prepalatial Mycenaean period (LH I-II), but if the trios of seals and rings from Grave Circle A relate to the concept of cooperative power, then we can identify groups of two and three seals from the early tholoi that may have functioned similarly (Rehak and Younger 2000). I give two examples. From the Kazarma tholos (LH I; CMS V, 577-85) come two Talismanic amygdaloids, two red lentoids (sard and cornelian), two quasi-Talismanic amygdaloids, and three cylinder seals, two of which are amethyst and two of which carry griffins. And from the Rutsi tholos (LH II), shaft 2 (CMS I, 269-74, /----/ ), come two cushions with VS.1A 345 /

female griffins, two three-sided amethyst prisms, anc three amygdaloids (one of which is glass and the other of gold with a netted bull); from the floor of the tholos (CMS I, 275-86) come two sardonyx lentoids, two agate lentoids, four cornelian lentoids, two cylinder seals of red stone (cornelian and sardonyx), a glass lentoid (cf. the glass amygdaloid from the shaft), and a second gold amygdaloid (this one with a wounded bull).

These pairs and trios of seals imply that two or three administrators shared authority and expressed that cooperation by owning seals with similar motifs and in similar shapes and materials (compare "replica" rings in Neopalatial Crete: Weingarten this volume). Evidence for a similar sharing of authority by lieutenants can be seen in sealings from Pylos (mentioned later).

\section{The Use of Seals in The Mycenaean Palaces}

A seal represents the individual who owns it; impressing the seal into clay is an act that stipulates that individual's responsibility in the transaction represented by the sealing. For example, while the clay stopper of a wine jar prevents contamination 
(e.g., CMS VS.1B, 348, from the Menelaion, LH II-IIIA), impressing the stopper certifies and guarantees its contents. For the Mycenaeans, seals are used only when it is necessary to document the participation of the particular individual who was responsible (immediately or ultimately) for the transaction that is being authenticated. Minoan seal use was more casual, authenticating most transactions regardless of the necessity to identify the responsible individual.

Except for a few other impressed jar stoppers (e.g., CMS I, 160-62; V, 669; and VS.3, 164, 218), one document sealing (CMS VS.3, 217), and one impressed nodulus (CMS I, 19), almost all other mainland seal impressions are found only on nodules (clay sealing around a knotted string) —and only one seal per nodule. Moreover, while many hundreds of seals impressed sealings from Minoan Crete, there are only some 250 seals that impressed some 500 sealings from the Mycenaean mainland (Palaima 1987). This restricted use parallels the restriction of Linear B writing to just tablets, labels, and nodules (Linear A was used more widely; Godart and Olivier, 1976-1985).

Most Mycenaean nodules document transactions between outlying production centers and the palace (for instance, a seal from Elis [CMS XI, 27] impressed a sealing from Pylos [CMS IS, 180] inscribed (Wr 1416) "nanny" [CAP ${ }^{\mathrm{f}}$ ], apparently recording the shipment of female goats). Most of the Pylos sealings written by persons outside the palace are inscribed in an "archaic" hand, reminiscent of the handwriting styles at Knossos almost two centuries earlier (Palaima 2000)—within the palace the official style was more modern.

Also within the palace, seal impressions were usually not necessary (the parties were well known), and few sealings (impressed or inscribed or both) are actually found in the Mycenaean palaces. We should imagine, therefore, that most sealings traveled out from the palaces to the outlying production centers accompanying raw goods to be finished. The excavation of the lower towns of Pylos and Mycenae will probably produce the kinds of documents that have been found in the houses on the Chania acropolis (Hallager and Vlasaki 1997, with earlier bibliography).

Another type of sealing no doubt to be found in the outlying production centers are those that were attached to tablets. Some leaf-shaped tablets (e.g., the Pylos Eb [landholding] and Sa [chariot wheels] series, and Thebes Ug 5 and 17) reveal traces of a horizontal string running through them, to which a sealing could have been fastened "with the impression of the seal of the scribal administrator" to be taken away by the person who had delivered commodities to the palace (e.g., Ameja in Pylos Sa 834 and Sh 736 and Akosota in Va 842) as a receipt that he had finished his task and furnished the commodities and "that the scribal administrator had indeed approved his work through inspection” (Palaima 1996). Such proof of delivery might be necessary if the furnisher were ever suspected of fraud, as in the trial of two Hittite supervisors during the reign of Hattusilis III (ca. 1286-1265 BC; Justus 1997; Palaima 1996).

Inscribed sealings record short, individual bits of information that are then entered on summary tablets (Palaima 2000). For instance, Pylos sealing Wr 1326 records the delivery of a bed (tablet Vn 851 presents the summary) and is impressed 
by a lentoid depicting a central octopus surrounded by dolphins (CMS I, 312); the seal may have belonged to an important individual: An octopus is painted on the floor directly in front of the throne, and dolphins are painted on floors in the “Queen's Megaron" suite (Hirsch 1977, 32-36, pls. 7.16, 7.17a, 9).

Inscribed and impressed sealings sometimes also give additional details, like those from Thebes that record individual animals, their sex, and their condition. Occasionally there is a pattern in seal use, too. For instance, Thebes seal type J (bull leaping) authorizes the delivery of pigs from Sameus (the swineherd?), while seal type L (two goats) authorizes fodder (logogram PYC), and R (two goats), male sheep (Aravantinos, Godart, and Sacconi 2002, 20, 51-75). Similar information for a feast at Pylos "when the wanax was initiated" must have arrived via similar sealed deliveries, summarized on tablets Un 2 and 138 (Palaima 2000).

At Pylos we can see delivery sealings. From the oil magazine (room 24) comes a sealing (Wr 1437) inscribed with "unguent" (logogram AREPA) and impressed with a lentoid that depicts crossed goats (CMS I, 382), presumably belonging to the supplier. Four sealings (Wr 1358-1361) from the Wine Magazine (room 105) each carry the inscription "wine" (logogram VIN); the impressing seals may have belonged to the vintners. Sealing Wr 1361 was impressed by a gold ring (CMS I, 361), while the other three sealings (1358-1360) were all impressed by a single lentoid (CMS I, 363, a stag hunt). Two of these sealings also record a man's name, both different and both in a different hand-presumably these are the vintner's lieutenants, who may have had access to the same seal. The seal would then signify that the person possessing it has ultimate authority, while the inscribed names would be those immediately responsible for the deliveries.

Mycenae also preserves delivery sealings. From the House of Sphinxes (LH IIIB middle; Bennett 1958) come eight sealings, seven impressed by the same seal (CMS I 163, in the Rhodian Hunt group) and an eighth (CMS VS.217, in the Island Sanctuaries group), whose reverse preserves the impressions of thick leather straps. These were found clustered for discard in the doorway of room 1; the inscribed sealings (Wt 501-507; figure 25.2) record pots (possibly those found in that room) that are summarized on the obverse of tablet Ue 611 found down the hall in the archives room 6 . The seals were presumably owned by the potter and/or the transporter.

Similarly, many sealings from the Arsenal at Knossos (Ws 1704, etc.) were found among the remains of two wooden boxes and hundreds of bronze points. Most of the sealings were inscribed by the same scribe with the appropriate logogram (Linear B *254 JAC), apparently to identify the contents for delivery; three sealings had been impressed by a single lentoid (CMS II.8, 305), probably belonging to the armorer (or his scribe), who then wrote the logogram across the impressions.

Unimpressed sealings are predictably inscribed with the kind of written information that the seal impression would have given visually. For instance, unimpressed Pylos labels (the Wa and Wo series) record personnel (e.g., the name of the supplier) and other details; Knossos label Wm 8499 records the name of a man furnishing cloth being supplied by another, while Wm 8493 records a collective at the place Setoija (Arkhanes?) furnishing a special te cloth to another place, Kirita. 
Figure 25.2. Mycenae sealing Wt 501 impressed by a lentoid (CMS I 163; drawing by the author).
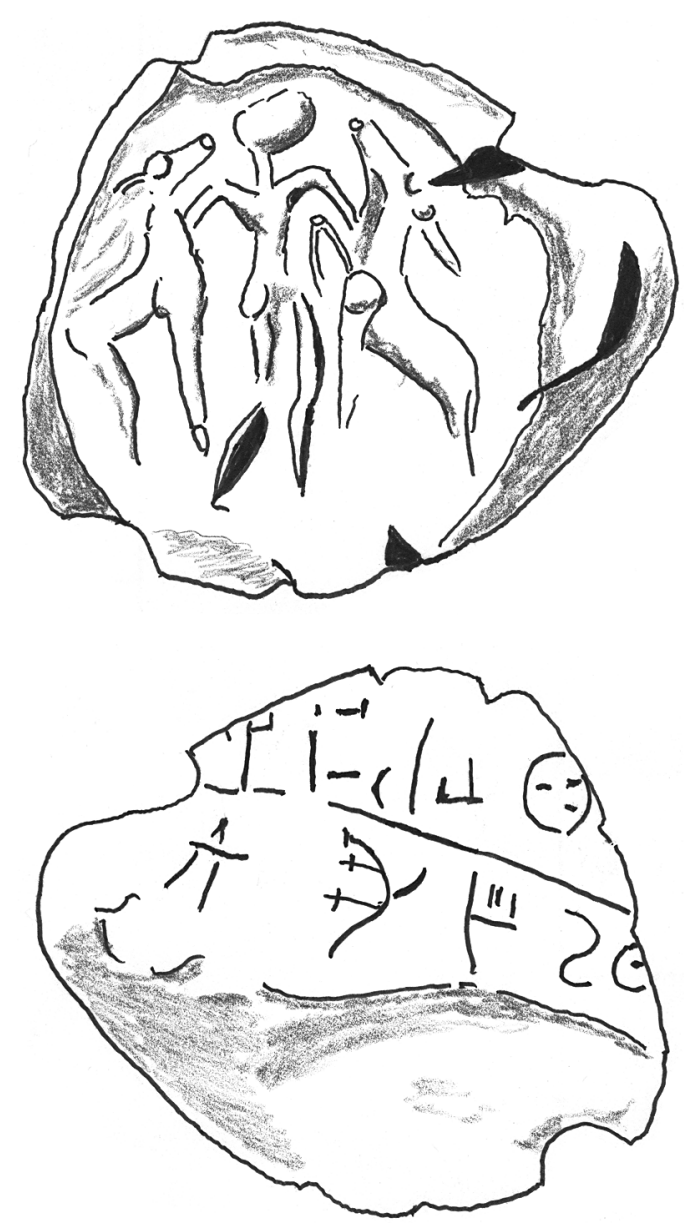

After inspectors within the palace received and unsealed the delivered goods, they would gather the sealings for discard, and the responsible administrator would have the deliveries summarized on tablets to be sent to the central archives. At Knossos, one sealing is impressed by a lentoid depicting a female dog (CMS II.8, 287); it is inscribed (Ws 8754) with the name of the purveyor, Kuwata, in the bureau of (opi) Anuwiko. We do not know the commodity that was sealed, nor do we know anything more about Kuwata (unless he is the immediately responsible scribe, Hand 101).

Anuwiko, however, may have been the "lawaketa" recorded on personnel tablets As 40+5093 and 1516 written by the same Hand 101; he would then be one of the most important officials at Knossos, second to the wanax (king) and more important than the qasirewe (classical "basileus") (Olivier 1968; Weingarten 1997). If the seal with the female dog is Anuwiko's (or his bureau's), it impressed sealings found in the west, south, and east wings of the palace. These sealings belong to the class known as "combination" sealings: A stringhole runs through them, and they were pressed up against a wicker basket, presumably the basket that held the 
recording tablets (see CMS II.8, fig. 29a, for the wicker impression on the reverse of Anuwiko's sealing).

At Pylos, combination sealings were found only in the Central Archives, room 8 (Weingarten 1991). There are six of these, impressed by three seals: CMS I, 302, a ring (?) depicting a man battling a lion; CMS I, 305, a ring with a bull-leaping scene; and CMS IS, 173, a ring with two men battling two lions-two certainly, maybe three, gold rings for our high-placed administrators within the palace. A regular sealing (CMS I, 307) was found next door in room 7 of the central archives. It was impressed either by the same ring as that with men battling lions or by a slightly different "replica." In any case, a "replica" ring does exist, the slightly larger, gold "Danicourt" ring (CMS XI, 272, said to come from Thessaloniki). Thus, we have, for the ultimately responsible administrator with access to the Central Archives, one, if not two, replica rings for his lieutenants.

\section{SUMMARY}

From this discussion it is apparent that Mycenaeans valued Minoan seals but produced few, if any, of their own for administrative use, though they did produce soft stone identity markers (the Mainland Popular group) when hard stone seals were no longer being supplied by Knossian artists (ca. 1300 BC).

In the Prepalatial period (LH I-II) pairs or trios of Mycenaean administrators, working cooperatively, may have used similar seals to conduct their shared duties.

In the Palatial period (LH III), Mycenaean administrators preferred to write their transactions out in full. When doing so was inconvenient (the sealing was too small, the transaction too complicated, or the participants were illiterate), then the personal seals of those responsible for conducting the transactions would be used in place of naming them. It is therefore probable that most Mycenaean sealings are delivery sealings to the palace (or palatial workshops outside the palace) accompanying commodities being furnished by persons in the outlying regions.

While some sealings accompanied goods that were circulating within the palace, others, the combination sealings, accompanied baskets of preliminary tablets to the central archives and recorded the receipt of commodities at the delivery points on the periphery. These were impressed by the seals that belonged to high officials (the lawaketa or the qasirewe) or by the replicas that belonged to their lieutenants, following an old tradition of shared cooperation on the mainland.

Mycenaeans may have commissioned a new seal stone style to mark their takeover of Knossos, but after that palace fell they no longer commissioned seals and were content to use heirlooms. 


\section{BiBLIOGRAPHY}

Aravantinos, Vassilis L., Louis Godart, and Anna Sacconi. 2002. Thèbes: Fouilles de la Cadmée. Vol. 3, Corpus des documents d'archives en Linéaire B de Thèbes. Rome: Istituti editoriali e poligrafici internazionali.

Bennett, Emmett L., Jr., ed. 1958. “The Mycenae Tablets II.” TAPS 48.1.

Dickers, Aurelia. 2001. Die spätmykenischen Siegel aus weichem Stein: Untersuchungen zur spätbronzezeitlichen Glyptik auf dem griechischen Festland und in der Ägäis. Rahden, Westfalia: Leidorf.

Evely, Don. 1993, 2000. Minoan Crafts: Tools and Techniques. An Introduction. SIMA 92: 1 and 2. 2 vols. Gothenburg: Åström.

French, Elizabeth B. 1989. “'Dynamis' in the Archaeological Record at Mycenae.” In Images of Authority: Papers Presented to Joyce Reynolds on the Occasion of her 7oth Birthday, ed. Mary M. Mackenzie and Charlotte Roueché, 122-30. Cambridge Philosophical Society Suppl. 16. Cambridge: Cambridge University Press.

Godart, Louis, and Jean-Pierre Olivier. 1976-1985. Recueil des inscriptions en Linéaire A: ÉtCrét 21, 1-5. 5 vols. Paris: Librairie Orientaliste Paul Geuthner.

Hallager, Erik, and Maria Vlasaki. 1997. "New Linear B Tablets from Khania." In La Crète mycénienne, 169-74.

Hirsch, Ethel. 1977. Painted Decoration on the Floors of Bronze Age Structures in Crete and the Greek Mainland. SIMA 53. Gothenburg: Åström.

Justus, Carol F. 1997. “The Case of the Missing dusdumi and lalami." Minos 29-30 (19941995): 213-38.

Makkay, János. 1984. Early Stamp Seals in South-east Europe. Budapest: Akadémia Press.

- 2005. Supplement to the Early Stamp Seals of South-east Europe. Budapest: Akadémia Press.

Marinatos, Spyridon, and Max Hirmer. 1960. Crete and Mycenae. New York: Abrams.

Müller, Walter. 2000. “Zu Stil und Zeitstellung des Bildthemas 'Herr der Löwen.' ” In Minoisch-mykenische Glyptik, 181-94.

Mylonas, George E. 1966. Mycenae and the Mycenaean Age. Princeton: Princeton University Press.

Olivier, Jean-Pierre. 1968. “La serie Ws de Cnossos.” Minos 9: 173-83.

Palaima, Thomas G. 1987. "Mycenaean Seals and Sealings in Their Economic and Administrative Contexts." In Tractata Mycenaea, ed. Petar Ilievski and Ljiljana Crepajac, 249-66. Skopje: Macedonian Academy of Sciences.

- 1996. "Sealings as Links in an Administrative Chain." In Administration in Ancient Societies: Proceedings of Session 218 of the 13th International Congress of Anthropological and Ethnological Sciences, Mexico City, July 29-August 5, 1993, ed. Piera Ferioli, Enrica Fiandra, and Gian Giacomo Fissore, 37-66. Turin: Ministero per i Beni Culturali e Ambientali Ufficio Centrale per i Beni Archivistici.

- 2000. "The Palaeography of Mycenaean Inscribed Sealings from Thebes and Pylos and Their Place within the Mycenaean Administrative System." In Minoischmykenische Glyptik, 219-38.

Pini, Ingo. 1995. "Die spätminoische Weichsteinglyptik." In Sceaux minoens et mycéniens, ed. Walter Müller, 193-207. CMS Beiheft 4. Berlin: Mann.

Poursat, Jean-Claude. 1996. Fouilles exécutées à Malia: Le quartier Mu III. Artisans minoens: Les maisons-ateliers du quartier Mu. ÉtCrét 32. Athens: L'École française d'Athènes.

Rehak, Paul. 1994. “The Aegean 'Priest' on CMS I.223." Kadmos 33(1): 76-84. 
, and John G. Younger. 2000. "Minoan and Mycenaean Administration in the Early Late Bronze Age." In Administration Documents in the Aegean and Their Near Eastern Counterparts, ed. Massimo Perna, 277-301. Turin: Centro internazionale di ricerche archeologiche antropologiche e storiche.

Vermeule, Emily T. 1967. “A Mycenaean Jeweler’s Mold.” BMFA 64(339): 19-31.

Weingarten, Judith. 1997. "The Sealing Bureaucracy of Mycenaean Knossos: The Identification of Some Officials and Their Seals." In La Crète mycénienne, 517-35. - 1991. 'Late Bronze Age Trade Within Crete: the evidence of seals and sealings,' in Bronze Age Trade in the Mediterranean. SIMA 90, ed. Nicholas H. Gale, 303-324. Jonsered; Åström.

Younger, John G. 1978. “The Mycenae-Vapheio Lion Group.” AJA 82: 285-99.

. 1979. "The Rhodian Hunt Group." In Papers in Cycladic Prehistory, ed. Jack L. Davis and John F. Cherry, 97-105. Institute of Archaeology, University of California at Los Angeles, Monograph XIV. Los Angeles: University of California at Los Angeles, Institute of Archaeology.

- 1981a. “The Island Sanctuaries Group: Date and Significance." In Studien zur minoischen und helladischen Glyptik. Beiträge zum 2. Marburger Siegel-Symposium 26.-30. September 1978, ed. Wolf-Dietrich Niemeier, 263-72. CMS Beiheft 1. Berlin: Mann: http://kuscholarworks.ku.edu/dspace/handle/1808/4497.

- 1981b. “The Mycenae-Vapheio Lion Workshop, III.” Temple University Aegean Symposium 6: 67-71.

- 1983. "Aegean Seals of the Late Bronze Age: Masters and Workshops, II. The First Generation Minoan Masters.” Kadmos 22: 109-36.

- 1984. "Aegean Seals of the Late Bronze Age: Masters and Workshops, III. The First Generation Mycenaean Masters." Kadmos 23: 38-64.

— 1987a. "Aegean Seals of the Late Bronze Age: Stylistic Groups VI. Fourteenthcentury Mainland and Later Fourteenth-century Cretan Workshops." Kadmos 26: $44-73$.

-1987b. "A Balkan-Aegean-Anatolian Glyptic Koine in the Neolithic and EBA Periods." A paper given at the VIth International Aegean Symposium, Athens, Greece, 31 August-5 September 1987; http://kuscholarworks.ku.edu/dspace/handle/1808/4303.

. 1988. The Iconography of Late Minoan and Mycenaean Sealstones and Finger Rings. Bristol: Bristol Classical Press.

_ 1992. "Seals? from Middle Helladic Greece." Hydra 8: 35-54; http://kuscholarworks. ku.edu/dspace/handle/1808/4302.

- 2000. “The Spectacle-eyes Group: An Assessment of Its Iconography, Techniques, and Style." In Minoisch-mykenische Glyptik, 347-60. 